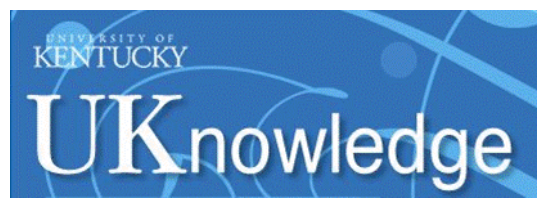

University of Kentucky

UKnowledge

$11-2015$

\title{
The Role of a Caring Disposition in Service Leadership
}

Daniel T. L. Shek

University of Kentucky

Xiang Li

Hong Kong Polytechnic University, China

Follow this and additional works at: https://uknowledge.uky.edu/pediatrics_facpub

Part of the Pediatrics Commons

Right click to open a feedback form in a new tab to let us know how this document benefits you.

\section{Repository Citation}

Shek, Daniel T. L. and Li, Xiang, "The Role of a Caring Disposition in Service Leadership" (2015). Pediatrics Faculty Publications. 202.

https://uknowledge.uky.edu/pediatrics_facpub/202

This Article is brought to you for free and open access by the Pediatrics at UKnowledge. It has been accepted for inclusion in Pediatrics Faculty Publications by an authorized administrator of UKnowledge. For more information, please contact UKnowledge@lsv.uky.edu. 


\section{The Role of a Caring Disposition in Service Leadership}

Digital Object Identifier (DOI)

https://doi.org/10.1515/ijdhd-2015-0453

\section{Notes/Citation Information}

Published in International Journal on Disability and Human Development, v. 14, no. 4, p. 319-332.

(C) 2015 Walter de Gruyter GmbH, Berlin/Boston

The copyright holders have granted the permission for posting the article here. 


\section{Daniel T.L. Shek* and Xiang Li \\ The role of a caring disposition in service leadership}

DOI 10.1515/ijdhd-2015-0453

Received April 18, 2014; accepted June 19, 2014; previously published online September 12, 2015

\begin{abstract}
A caring disposition is an important and fundamental attribute of a service leader. At the Hong Kong Polytechnic University, a lecture on a caring disposition in the subject "Service Leadership" was designed to help students understand the importance of caring dispositions. The curriculum design with reference to the basic concepts and theories as well as the content of the lecture are presented in this paper. In the first part of the paper, several uncaring cases are presented to serve as negative examples to inspire students' reflection on caring leaders. Then, the three most important traits of a caring disposition, including awareness, love and nurturing people are introduced. Next, the relationships between a caring disposition and service leadership are analyzed and practical ways of improving a caring disposition are proposed. Finally, the impacts of a caring disposition on the leaderfollower relationship are discussed. To provide a general overview of this lecture, the content including detailed lecture sessions and four designed activities relevant to a caring disposition are also presented in the paper.
\end{abstract}

Keywords: caring disposition; caring leader; leaderfollower relationship; service leadership; university education.

*Corresponding author: Daniel T.L. Shek, PhD, FHKPS, BBS, SBS, JP, Associate Vice President (Undergraduate Programme) and Chair Professor of Applied Social Sciences, Faculty of Health and Social Sciences, Department of Applied Social Sciences, The Hong Kong Polytechnic University, Room HJ407, Core H, Hunghom, Hong Kong, P.R. China, E-mail: daniel.shek@polyu.edu.hk; Center for Innovative Programs for Adolescents and Families, The Hong Kong Polytechnic University, Hong Kong, P.R. China; Department of Social Work, East China Normal University, Shanghai, P.R. China; Kiang Wu Nursing College of Macau, Macau, P.R. China; Hong Kong Institute of Service Leadership and Management, Hong Kong, P.R. China; and Division of Adolescent Medicine, Department of Pediatrics, Kentucky Children's Hospital, University of Kentucky College of Medicine, Lexington, KY, USA

Xiang Li: Department of Applied Social Sciences, The Hong Kong Polytechnic University, Hong Kong, P.R. China
Introduction

Greenleaf [1] stated that the first priority of any leader should be putting others first, including employees, customers and the community. In other words, a caring disposition in leaders is very important, and leaders have an obligation to care for others. However, not all leaders have caring dispositions. For example, the minimum wage of employees in Hong Kong was not legislated until 2011. After much debate and struggling negotiation of many organizations (e.g. Hong Kong Confederation of Trade Unions, Hong Kong Federation of Trade Unions), the statutory minimum wage rate was revised from HK\$28 to HK\$30 per hour on 1 May 2013. The Minimum Wage Ordinance aims at striking an appropriate balance between forestalling excessively low wages and minimizing the loss of low-paying jobs [2]. As a matter of fact, there was no specific ordinance regulating the minimum wage before 2011. If hard work cannot support basic living, is it possible for employees (i.e. followers) to have commitment to their employers (i.e. leaders) and work? Do those exploitative leaders care about their followers? Another example is manufacturers in mainland China who provide customers with poor quality products, such as food with drainage oil, milk powder with melamine and eggs with Sudan dyes. Do those "black heart" merchants care about their customers (i.e. service provider-customer relationship)? A further example involves smart phones. Smart phones are more and more popular around the world, with the result that many people indulge in the virtual world at the expense of communicating with others in the real world. Do manufacturers and marketing teams alert customers to the "dark side" of modern advanced technology? What should they do to counter the influence of the addiction culture?

How to balance profit maximization and the needs of customers and communities? How to deal with the relationship between leaders and their followers? What is the role of caring dispositions of leaders in service leadership? These are important questions to be asked because the service leadership model focuses on a caring disposition as an integral attribute of a service leader. 


\section{Caring disposition}

As a multi-dimensional construct with affective, cognitive and behavioral components, a caring disposition in leaders can be defined as the behavioral and structural conditions that motivate followers to explore new possibilities, give unconditional respect to people, make provisions for others' growth and development and cultivate and maintain good interpersonal relationships [3]. A caring disposition is unconditional and generative, which is a highly developed skill based on psychosocial, spiritual and physiological understanding of self and others [4] and involves a sense of empathy and responsibility for others and for society [5]. Leaders are expected to serve peoples' interests in an unselfish manner [6]. Habecker wrote "The true leader serves. Serves people. Serves their best interests, and in so doing will not always be popular, may not always impress. But because true leaders are motivated by loving concern rather than a desire for personal glory, they are willing to pay the price" [cited by 7, p. 75]. Einstein also believed that "only a life lived for others is the life worthwhile" [8]. In short, the objective of "the servant as leader" is to stimulate thought and action for building a better and more caring society [9].

Because the primary focus of a leader is to serve others, a caring disposition is a priority for a service leader [10]. Greenleaf [11] believed that a great leader should be a servant first. Fry et al. [12] also supported that servant leaders are expected to have an attitude that flows from a deep-rooted and natural inclination to serve followers at work. As a desirable and influential behavior, care can make a difference in peoples' lives and organizations [13]. The best test is "Do those served grow as persons? Do they, while being served, become healthier, wiser, freer, more autonomous, more likely themselves to become servants? And what is the effect on the least privileged in society; will they benefit, or, at least, not be further deprived?” [14, p. 19].

The emphasis on a caring disposition is intrinsic to the servant leadership model. Spears [15] identified a set of ten characteristics of servant leaders, including listening, empathy, healing, awareness, persuasion, conceptualization, foresight, stewardship, commitment to the growth of people and building community. Some characteristics are more related to the traits of leaders themselves (e.g. foresight) whereas some characteristics stress more the traits of interactions between leaders and followers (e.g. empathy). van Dierendonck [16] postulated that the relationship between servant leaders and followers was based on the care, concern and benevolence of leaders for followers [17]. Sendjaya et al. [18] argued that "servant leadership is a manifestation of altruistic love in the action of pursuing transcendent vision and being driven to satisfy needs for calling and membership" (p. 404). In fact, a caring disposition in leaders is not only very important in servant leadership, it is also emphasized in many other kinds of leadership, such as spiritual leadership, which establishes a social/organizational culture based on altruistic love and genuine care between leaders and followers [19]; transformational leadership, which emphasizes individualized consideration and care about each other [20]; and supportive leadership, which expresses leaders' concern and care for followers' needs and preferences [21].

A survey of the literature shows that awareness, love and nurture are three most important traits of caring dispositions of service leaders.

\section{Awareness}

Awareness is crucial to the development of servant leaders who have a keen sense of what is happening around them and stay alert to all different kinds of cues from the environment [22]. Awareness strengthens an individual's effectiveness as a leader [10] by helping him or her understand the issues of ethics and values from a more integrated and holistic perspective [15] and avoid being fooled by appearances [22]. Through a deeper understanding of the basic nature of issues, awareness facilitates leaders in developing meaningful solutions to critical concerns [23]. Awareness not only requires developing a sense of unity by integrating all aspects of life, but it also requires leaders to pay attention to the members in their institutions or organizations [11]. Spears [15] asserted that awareness encompasses "getting in touch with one's own inner voice and seeking to understand what one's body, spirit and mind are communicating" (p. 4).

Listening is a foundational skill for servant leaders [24] that is different from simply hearing others' speaking [25] but that can be learned and practiced [22]. Rai and Prakash [3] argued that active listening involves listing patiently to people, understanding their opinions, probing their views of identified issues and seeing subjects from others' perspectives, such as in the eyes of followers. Active listening is an important way of reaching awareness. It can be regarded as respect by leaders for the viewpoints of followers [26], and it also can be regarded as leaders' extra emphasis on the needs, priorities and work problems of followers [3]. Active listening of leaders diminishes the psychological barrier of followers [3], with the result that followers are more likely to talk about their own opinions and share personal ideas and experiences. 
Active listening requires people to stop talking too much about themselves and start focusing on others. In particular, leaders should try to understand the real meaning of what other people say and give timely responses. Listening with regular reflection is essential to the growth of a leader [15]. Spears [15] believed that the most successful servant leaders are skilled listeners, who are really involved in the conversation through conveying sincere interest in speakers' words, caring for their feelings and making suitable responses [27]. Active listening allows leaders to understand the problems and difficulties their followers encounter, and to figure out certain strategies to support people mentally and help people practically.

\section{Love}

Love, hardly a definable term with both subtle manifestations and unlimited liability [11], is considered as an affect that is similar to benevolence, a core virtue in traditional Chinese philosophy [28]. As an important trait of a caring disposition, love is a genuine care for others by showing sensitivity to others' personal concerns and interests [29]. Ferris [30] perceived love as a means to an end, a consciously chosen commitment to act in certain ways. Love can be considered to be a sense of wholeness, harmony and well-being produced through care, concern and appreciation for both self and others [19].

The manifestation of love can increase productivity and organizational effectiveness [30]. With love, the workplace can be a warm home and a part for both leaders and followers. Without love, leaders only control, manipulate and use manpower [30]. da Vinci said "The noblest pleasure is the joy of understanding” [cited by 31, p. 4]. More and more, successful leaders have recognized that they need to reach followers' hearts before asking them for a hand [32]. Only when a leader makes a connection between love and energy, is he or she able to make the shift from managing skills to leading people [30] because until people feel understood, they will not be open to the influence of leaders [33].

Empathy is love in action [34], which can be actively and intently used to connect with and understand others. Empathy was defined by Merriam [35] as "the imaginative projection of a subjective state into an object” (p. 369). In other words, it is about a person's ability to understand and experience another's feelings, emotions, motives and values [36]. In addition to enabling leaders to extend much consideration to followers, empathy enables leaders to forgive subordinates' shortcomings [36]. Leaders with empathy assume the good intentions of their coworkers, even if one finds it necessary to refuse to accept the behavior or performance of others [15, 37]. As Kouzes and Posner [38] stated, "The best-kept secret of successful leaders is love: staying in love with leading, with the people who do the work, with what their organizations produce, and with those who honor the organization by using its products and services. Leadership is not an affair of the head. Leadership is an affair of the heart” (p. 351).

\section{Nurturing a caring disposition}

Although followers need to seek opportunities to serve and lead, leaders in a more dominant position should actively identify opportunities to enhance the capabilities of followers [23]. With a natural desire to serve people, servant leaders always pursue opportunities to influence others' lives and make a difference for them [22]. Care is about attention, solicitude and active involvement with other people [6]. In addition to paying attention to the concerns and needs of followers, another important obligation of leaders is to nurture followers with needs of personal development [39]. Stone et al. [40] postulated that "servant leadership is a belief that organizational goals will be achieved on a long-term basis only by first facilitating the growth, development, and general well-being of the individuals who comprise the organization" (p. 355). Thus, servant leaders need to develop people and further help them strive and flourish [41].

To bring followers together for a common purpose, leaders not only need to indicate a direction for their followers, but they also need to support followers and enable them to do their best [42]. As people builders, leaders should have the commitment to nurture the personal and professional development of followers and help them reach their full potential and realize their dreams [23]. Showing care and concern for others at all times is not enough. Leaders should learn to appreciate every individual's strengths and identify his or her specific challenges or needs, and then provide effective support and encouragement when necessary. Even a servant leader should prepare to sacrifice his or her self-interest for the sake of others because of the natural service calling of a service leader [22]. As servant leaders have a strong commitment to help the growth of people spiritually, professionally and personally, specific value and contributions of followers beyond their tangible contributions as workers in an organization should be acknowledged, valued and celebrated by leaders $[22,23]$. 


\section{Relationship between caring disposition and service leadership}

Leadership consists of two aspects: a visionary part and an implementation part [43]. Even if leadership starts with a clear and right direction, leaders cannot achieve a goal all by themselves because they need their followers [43]. Thus, the implementation part is as important as the visionary part. As a caring disposition is aligned well with the principles of service leadership [23], the importance of a caring disposition in leaders in the implementation part is beyond doubt. A caring disposition helps the personal and professional growth of followers, and it also improves organizational effectiveness [23].

A caring disposition of leaders and its positive impacts on followers are highly related and influence each other. If followers feel sufficient care in organizations, they tend to truly experience belonging to the organization and become more powerful [30]. If followers are treated as ends rather than means to an end, they tend to reach their potential and perform optimally [42]. Care not only enhances the self-worth of followers [3], but it also makes them move above their self-interest and engage in collective work [24]. If leaders have an awareness and concern to discover and acknowledge followers' inherent strengths, needs and values, followers are more likely to comply with the requirements of leaders because the caring disposition of leaders make followers trust and follow them. The result is that leaders are allowed to maintain their authority and power and further promote their own career success and development of the organization [23] because leaders' power is generated from people who are led. Hsün Tzu said "The prince is the boat; the common people are the water. The water can support the boat, or the water can capsize the boat" [cited by 44, p. 175].The higher the position a leader reaches, the greater the demand and difficulties of working with others that will be faced by him or her.

Leadership is an influence process about how leaders help followers accomplish their goals [43]. Caring dispositions of leaders lead to better work performance by their followers [45]. In addition to positive effects on followers, caring dispositions of service providers are closely related to service recipients across different professionals [46]. For example, the understanding and care of teachers have positive effects on the level of students' learning motivation and performance [47]; more care delivered by care providers to patients lead to higher levels of patient satisfaction and more successful treatment [48]; engineers' responsibility and care for the quality of service increases the satisfaction of customers [49]. Obviously, a caring disposition does not only benefit individuals, it also satisfies the needs of the community. For example, if people take more action to care for the environment (e.g. reduce waste, save energy), the environment can be protected and sustainable development can be promoted. Broadly speaking, if people care for each other (e.g. care for the vulnerable groups and people in need), society will become healthier and more harmonious.

\section{Ways to develop caring disposition}

First, a caring heart is a precondition for the development of a caring disposition. Every leader is expected to have a servant's heart [42]. As pointed out by Neill and Saunders [23], leading others has less to do with directing people and more to do with serving them. Servant leaders lead with love, humility, altruism, trust, vision, empowerment and servanthood [50]. Developing a caring disposition is a process that increases awareness and love for others, and reaches the goal that leaders are aware of peoples' needs, including developmental needs when leading others. Unfortunately, with the growth of egocentrism among young people, they become more self-centered with more self-love than love for others.

Second, in addition to a caring disposition, capabilities of leaders should also be strengthened correspondingly because servant leadership is positively related to leaders' empathy and competence from the perspectives of followers [51]. Particularly at the most difficult time, followers only truly rely on leaders who are both competent and committed to their well-being [52]. Unfortunately, there are few systematic programs helping young people to develop such qualities.

Third, a caring disposition can be improved by encouragement and facilitation [42] so that participation in more activities that involve the practice of collaboration is a good approach to develop a caring disposition. A care-driven leadership intends to build and strengthen the relationship between leaders and their followers [36]. Experiencing care enhances the willingness of followers to help others [53]. Meanwhile, service leaders will not only be rewarded with positive responses (e.g. respect, praise, cooperation), but they will also realize their own values through helping others. Good cooperative relationships are expected to be formed by the collective effects of leaders and followers. Given that a positive and supportive work environment is essential in an organization, a good atmosphere guarantees the development of a sense of team spirit and organizational unity. 
Fourth, developing a higher sense of purpose in life can facilitate the development of a caring disposition. Patterson [50] stated that "To serve and see life as a mission of service and this calling to service induces an acceptance of responsibility for others" (p. 25). The origin of servant leadership is a fundamental desire to serve, and the ultimate aim of a servant leader is to meet the highest priority needs of people being served [10]. Thus, only when a leader has the mission of serving those who have served us [23], the appreciation from followers may positively promote the cooperative and harmonious atmosphere and further build a healthy relationship between leaders and followers.

Finally, a caring disposition can be nurtured through participation in voluntary work such as service learning. Through serving the needy groups in the community, young people can acquire the mentality and skills of caring for other people. It is noteworthy that service learning has become popular in the higher education sector in the past decade.

\section{Discussion}

A caring disposition can create a better leader-follower relationship, and then the quality of the leader-follower relationship influences the attitudes and behaviors of followers [54]. Care is heartfelt, selfless and focused on others' needs, and this disposition can touch followers' deeply. In addition to competencies, leadership effectiveness is governed by the character and caring behaviors of leaders [55]. Thus, judgments of followers about a leader are decided by his or her caring disposition to a great extent.

Servant leadership is a mix of idealism and pragmatism [23]. Ideally, caring is a mutually responsive relationship for both carer (i.e. leaders) and cared for (i.e. followers) who experience giving and receiving as important parts of their growth [56]. Greenleaf [10] supposed that servant leaders should have a sense of the unknowable and have the ability to foresee the unforeseeable. Personal values, beliefs and characteristics in the leadership position set the tone and provide the model for a caring disposition [4]. Caring attitudes of servant leaders towards the needs and difficulties of followers result in the openness in organization [3]. Through providing vision, servant leaders gain credibility and trust from followers [57]. Hence, effective communication between leaders and their followers influences the followers and finally makes the leaders' vision come true [57]. In many aspects, service leadership has an overlap with servant leadership in the aspect of caring dispositions.

To build the followership of subordinates, leaders should enhance the well-being of subordinates by exhibiting care [58]. Leaders display care for the professional and personal lives of their followers in exchange for their unquestioning loyalty and compliance [59]. Goal achievement depends on the collective efforts and good interpersonal relations between servant leaders and followers [3]. Followers, who are not machines but human beings, simply adding oil or providing instructions to them is not enough. A caring disposition is needed as it is a necessary precondition that people are willing to open their heart to leaders. The interaction between leaders and their followers is vital for achieving their common goal because a caring leader can inspire their followers to have a moral obligation [20], while a harsh, pushy and demanding leader may make followers complete tasks but followers may not have the commitment to their work.

An ancient Chinese saying is "Do not give up doing good things though they may be minor matters" (wu yi shan xiao er bu wei). Leadership does not only refer to a big change to the world, but it also could be used to describe some simple and small things that one influences the other more than money, power and status. "Never stop doing little things for others. Sometimes those little things occupy the biggest part of peoples' hearts" [60]. A caring disposition seems to be very trivial and easily ignored, but it is very powerful. As remarked by Buscaglia, "Too often, we underestimate the power of a touch, a smile, a kind word, a listening ear, an honest compliment, or the smallest act of caring, all of which have the potential to turn a life around" [cited by 61, p. 8]. Care is an effective approach to connect one person to another, which is a basic relationship between leaders and their followers. Servant leaders care for the interests and needs of their followers, which makes followers reciprocate leaders' support in a trusting and cooperative manner that goes beyond the basic job requirements [62]. In summary, care can be applied to relationships with colleagues, followers and the wider society [42] and helps to create a secure, honest, trustful and open climate in an organization [63].

\section{Lecture content}

In addition to leadership competence and character strength, a caring disposition is an important attribute in service leadership. It can be understood as an attitude of involvement in satisfying the needs of others. Caring 
dispositions could be specifically reflected in one's awareness, listening, empathy and desire to nurture others' growth [64]. A caring leader is highly trusted and respected by followers and thus is effective in inspiring others' commitment to the development of groups. For the purpose of cultivating a caring disposition among students who are expected to be service leaders in the future, this lecture will introduce the characteristics of caring leadership, explain the relevance of a caring disposition to service leadership and discuss the ways for students to promote a caring disposition.

After this lesson, students are expected to (a) understand the nature of a caring disposition in a genuine sense; (b) recognize the practice of caring for others; (c) appreciate the importance of having a caring disposition for a service leader; (d) recognize the typical social issues related to a caring culture; and (e) reflect on their performance and explore ways to promote a caring disposition.

\section{Lecture outline: Part I: controversial issues and topics}

The purpose of this part is to draw students' attention to leadership without care and highlight the importance of a caring disposition for a leader. First of all, we introduce the key propositions of service leadership to students and let them understand that high quality service is related to a caring disposition in leaders in addition to their moral character and competence. Several students will be asked to voice their personal opinions about service leadership. Next, we take four real cases to illustrate the behaviors of some leaders without caring dispositions. Two examples are related to a lack of concern for followers (i.e. scandals of Foxconn in mainland China and the minimum wage in Hong Kong), and the other two examples are related to a lack of concern for customers (i.e. scandals of milk powder with melamine in mainland China and plasticizer-tainted drinks in Taiwan). The purpose of discussing real examples is to make students think about one point: service leaders are expected to provide a high quality of service through possessing caring dispositions. Students are also invited to consider some real cases in daily life that are totally opposite to caring behaviors. Then, two to three students will be invited to share their opinions on those leaders without caring dispositions. Finally, the teacher wraps up by emphasizing the importance of balancing profit maximization of an organization and the needs of the public and the self-interest of leaders and the welfare of followers.

\section{Part II: caring in service leadership}

The purpose of this part is to facilitate students' understanding of caring dispositions in service leadership. First of all, we emphasize the expectations for caring dispositions in service leaders, the primary focus of whom is to serve others and motivate and empower their followers by displaying caring behavior.

Second, students are expected to understand three important traits of service leadership including awareness, love and nurture [6]. Awareness is generated by paying attention and listening actively; love is expressed by exhibiting empathy; and nurturing followers is a natural desire and commitment of service leaders. The teacher tries to make students understand that in addition to caring for others as always, leaders sometimes should sacrifice their own interests to serve and develop their followers.

Third, a group discussion on caring dispositions in different occupational roles is conducted. In this activity, students are required to reflect on and discuss how service leaders should care for their followers and how they should demonstrate their caring dispositions across different occupations. Appendix 1 describes several different occupations including marketing manager, writer or author, fitness trainer, fashion designer and electrical technician. Each group will be assigned one occupation to discuss. Students are expected to discuss how a leader in the assigned occupation demonstrates his or her caring disposition at work.

In Appendix 2, students are invited to fill in three parts, including certain occupations under discussion, people or some aspects that need to be cared for and caring acts that need to be adopted. Students are reminded that when considering suitable behaviors the leader should do, they only need to think about the aspects related to the given occupation rather than the general good performance of the leader. For example, a teacher may need to take many roles at the same time, such as a father or mother, an amateur athlete or a volunteer of a service organization in addition to teaching. But in the discussion, students only need to focus on his or her professional role as a teacher. Next, an example about the occupation of a teacher will be introduced to students and facilitate their discussion. A teacher is usually expected to care for students' academic performance, physical development, mental health and other related aspects and make effective responses to students' needs through giving timely help and advice. Additionally, teachers should take the initiative to hear students' voices and learn more about their real opinions and heart through communicating with them in a 
supportive, encouraging and caring manner rather than rigorous, critical or apathetic one.

After the discussion, several students will be invited to share their group opinions. Through this discussion, students are expected to understand that all jobs need leaders with caring dispositions although the specific expectations of a certain post are different. Finally, the teacher wraps up the discussion with an emphasis on the necessity of having a caring disposition across different occupations.

\section{Part III: importance of caring disposition}

The main purpose of this part is to help students understand the nature of a caring disposition and the relationship between a caring disposition and service leadership. First, students are expected to know "leaders as servants". Students should know that a leader has the obligation and mission to bring his or her followers together for a common purpose and the higher demand and difficulties that will be faced by the leader once he or she reach a higher position.

Next, students are expected to understand the relationship between caring dispositions of service leaders and trust of the followers. A general rule is that as long as leaders can discover followers' needs and acknowledge their values, it is possible for followers to commit to their work. A good interaction between caring behaviors to followers and trust in leaders results in leaders being allowed to exercise and maintain their power in the organization.

After introducing the relationship between caring dispositions and service leadership, an inspiring TED video called "A Story about Lollipops" will be played in class. The underlying meaning behind this story is that some small things you do for others have the possibility to influence and help others a lot, though you may not be aware of the importance of your conscious or unconscious good act. Through watching this video, students are expected to recall whether they have similar experiences in their life and understand the value of such a small but influential act. Students are encouraged to display their caring behaviors even if these acts are too small to be remembered by themselves.

Following students' discussion on the "lollipops story", students should prepare a role play based on the guidance and instruction outlined in Appendix 3, which includes three scenarios about the topic of "What should a caring person do?” Each group will be assigned one scenario to discuss and nominate some group members to role-play the scenario of what a caring person should do in the given situation according to their understanding. The aim of this role-play is to help students understand the attributes of a caring disposition and how to display caring behavior. After the role-play session, students will be invited to share their opinions on the various expressions of a caring disposition in different contexts. Finally, the teacher wraps up this part by highlighting the importance of a caring disposition to self and others.

\section{Part IV: ways to a develop caring disposition}

The purpose of this part is to help students reflect on their own performance and identify some ways to promote caring dispositions. The teacher may suggest three approaches to develop a caring disposition. The first suggestion is to increase awareness through being conscious of others' needs, valuing the importance of satisfying others' needs and learning to appreciate the strengths of others. The second suggestion is to strengthen the caring capability through participating in different kinds of activities involving the practice of collaboration. The third suggestion is to develop a higher sense of purpose in life. Next, students are encouraged to reflect on the value of service learning in helping students develop their caring disposition. Students are expected to think about two questions: "Under what circumstance will they be willing to sacrifice their own interests for others?" and "How should they make a balance between their self-interest and others' welfare?"

Finally, students are invited to conduct self-reflection based on four questions as follows: 1) Are you willing to sacrifice your own self-interest for others? 2) Do you really value others' ideas, advice or comments? 3) During a conversation, are you truly engaged? Or are you simply waiting for your turn to speak? 4) Are you aware of the needs of your friends, family members and the society? To facilitate students in reflecting on their experiences with caring dispositions, students are encouraged to fill in Appendix 4 to identify three acts that they have done to show care for others, and three acts (if any) that they feel were not so caring. Additionally, students are encouraged to think about how to develop them as caring service leaders in their future career through identifying three specific ways they would promote their caring dispositions. After inviting two to three students to share their experiences in class, the teacher wraps up this part by emphasizing the importance of cultivating a caring disposition. 


\section{Part V: conclusion}

The teacher ends this class by summarizing the key points of this lecture including caring dispositions in service leadership, importance of caring dispositions and ways to develop caring dispositions. Moreover, the teacher will summarize the core belief related to this lecture - "Core Belief 3 - Leadership effectiveness is dependent on possessing relevant situational task competencies plus being judged by superiors, peers, and subordinates as possessing character and exhibiting care" [55]. By the end of this lecture, two to three students are invited to share their thoughts on a caring disposition in service leadership and the knowledge they gained from this lecture.

Acknowledgments: The Service Leadership research project at The Hong Kong Polytechnic University is financially supported by the Victor and William Fung Foundation. 


\section{Appendix 1}

\section{THE HONG KONG POLYTECHNIC UNIVERSITY \\ DEPARTMENT OF APPLIED SOCIAL SCIENCES \\ APSS2820 Service Leadership}

Lecture Eight: Caring Disposition and Service Leadership

\section{Caring in Occupational Roles}

Cut the five occupations along the dotted lines. Ask students from each group to draw lots and then invite their group mates to perform the tasks based on the occupation they have drawn.

\section{A: Marketing Manager}

B: Writer/Author

D: $\quad$ Fashion Designer 


\title{
Appendix 2
}

\author{
THE HONG KONG POLYTECHNIC UNIVERSITY \\ DEPARTMENT OF APPLIED SOCIAL SCIENCES \\ APSS2820 Service Leadership
}

Lecture Eight: Caring Disposition and Service Leadership

Caring in Occupational Roles

\section{Caring in Occupational Roles}

Based on the occupation you have drawn, please discuss in your group how one should behave in this job, through which his/her caring disposition can be well reflected? In other words, what and how should he/she care? Show your answers by filling the part below.

Reminder: You can just consider the aspect of care related to the given occupation rather than multiple roles one takes. For example, a teacher could also be a father, an amateur athlete, and a volunteer of service organization at the same time, but you just need to think about what he should do as a teacher.

As a service leader, a/an

$$
\text { (What occupation?) }
$$

Should care

$$
\text { (Which people? Which aspects?) }
$$

Accordingly, he/she should

$$
\text { (What actions?) }
$$




\section{Appendix 3}

\section{THE HONG KONG POLYTECHNIC UNIVERSITY DEPARTMENT OF APPLIED SOCIAL SCIENCES APSS 2820 Service Leadership}

Lecture Eight: Caring Disposition and Service Leadership

\section{What Should A Caring Person Do?}

Following students' discussion on the story, request each group to draw one from the three scenarios below, and role play what a caring person should do in that situation according to their understanding.

\section{Scenario A:}

You are leading your team to work on an urgent project, which has made your past week really hectic. As scheduled, every member's work has to be finished and submitted for a final compilation the day after tomorrow to meet the deadline. However, this morning, a member of your team, Jason, made a call to you to apply for a day's leave because he got a severe fever. As a result, his part of the work has to be delayed.

What would you do?

\section{Scenario B:}

Betty, Tina and you have been good friends for a long time, but the two drifted apart due to some trivial matters several days ago and have avoided each other till now. For this weekend, you have planned to go shopping with Tina.

However, just a few minutes before the date, Betty called you and invited you to watch a popular movie together.

What would you do?

\section{Scenario C:}

You and several classmates have just delivered a group project presentation. You all feel bad because Lucy's performance has dragged down the overall grade for the group. Some of you blame her for preparing poorly for such an important task, and Lucy looks very sorry. She apologizes to everyone and explains that for the past days, she had to take care of her sick mother, which brought her many difficulties when preparing for the presentation.

What would you do? 


\section{Appendix 4}

\section{THE HONG KONG POLYTECHNIC UNIVERSITY DEPARTMENT OF APPLIED SOCIAL SCIENCES \\ APSS 2820 Service Leadership}

Lecture Eight: Caring Disposition and Service Leadership

$$
\text { Are You a Caring Person? }
$$

Identify three acts you have done that were caring for others. Recall three acts (if possible) that you feel not so caring. Put your answers into the following tables.

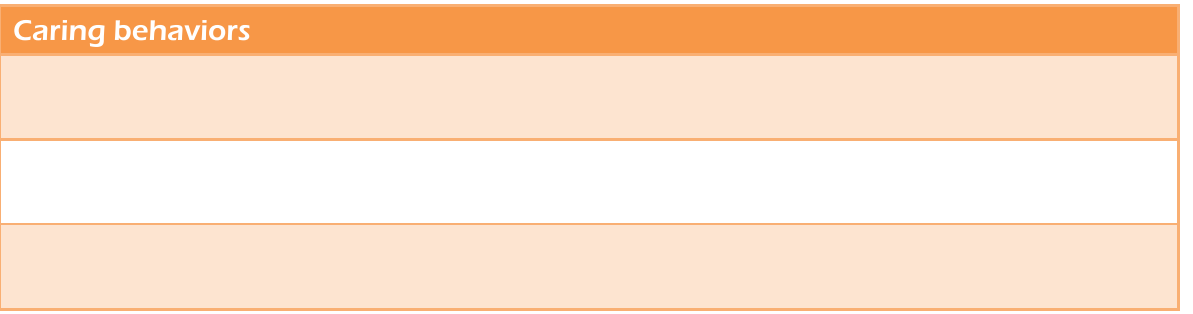

\section{Behaviors not so caring}

Based on your reflection, please think about how to develop yourself towards a caring service leader in your future career. Identify three specific ways you would do to promote caring disposition.

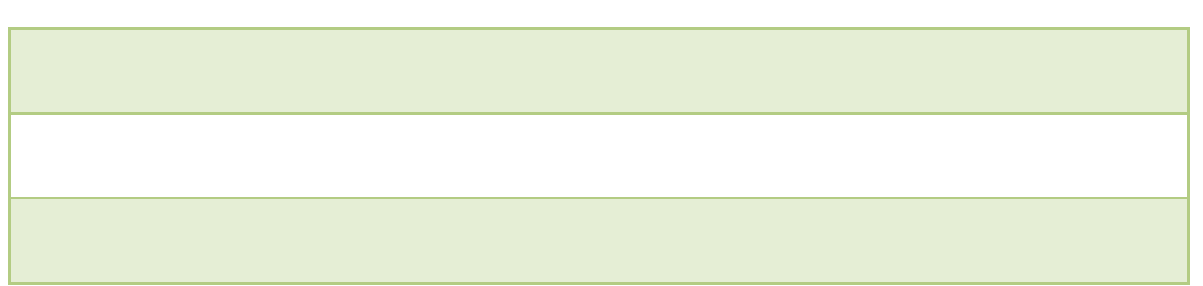




\section{References}

1. Greenleaf RK. The servant as leader. Newton Centre, MA: The Robert K. Greenleaf Center, 1970.

2. Labour Department. Labour legislation - overview of major labour legislation. Available at: http://www.labour.gov.hk/eng/ legislat/content5.htm. Accessed: 29 Nov 2013.

3. Rai R, Prakash A. A relational perspective to knowledge creation: role of servant leadership. J Leadersh Stud 2012;6:61-85.

4. Morath JM, Manthey M. An environment for care and service leadership: the nurse administrator's impact. Nurs Adm Q 1993;17:75-80.

5. Radke-Yarrow M, Zahn-Waxler C. The role of familial factors in the development of prosocial behavior: research findings and questions. In: Olweus D, Block J, Radke-Yarrow M, editors. Development of antisocial and prosocial behavior. New York: Academic Press, 1986:207-33.

6. Ciulla JB. Leadership and the ethics of care. J Bus Ethics 2009;88:3-4.

7. Tuso PJ. Learn to serve. Perm J 2006;10:75-6.

8. Einstein A. Quotes. Available at: http://einstein.biz/quotes.php. Accessed: 09 Dec 2013.

9. Spears LC. The power of servant-leadership: essays. San Francisco, CA: Berrett-Koehler, 1998.

10. Greenleaf RK. Servant leadership: a journey into the nature of legitimate power and greatness. Mahwah, NJ: Paulist Press, 1977.

11. Greenleaf RK. The servant as leader. In: Beazley H, Beggs J, Spears LC, editors. The servant-leader within: a transformative path. New York: Paulist Press, 2003:29-74.

12. Fry LW, Matherly LL,Whittington JL, Winston BE. Spiritual leadership as an integrating paradigm for servant leadership. In: Singh-Sengupta S, Fields D, editors. Integrating spirituality and organizational leadership. India: Macmillan, 2007: 70-82.

13. Kitzrow MA. An overview of current psychological theory and research on altruism and prosocial behavior. In: Bringle RG, Duffy DK, editors. With service in mind: concepts and models for service-learning in psychology. Washington, DC: American Association for Higher Education, 1998:19-34.

14. Greenleaf RK. Servant-leadership. In: Spears LC, editor. Insights on leadership: service, stewardship, spirit, and servant-leadership. New York: John Wiley, 1998:15-20.

15. Spears LC. Tracing the growing impact of servant-leadership. In: Spears LC, editor. Insights on leadership: service, stewardship, spirit, and servant-leadership. New York: John Wiley, 1998:1-12.

16. van Dierendonck D. Servant leadership: a review and synthesis. J Manage 2011;37:1228-61.

17. Winston BE, Ryan B. Servant leadership as a humane orientation: using the GLOBE study construct of humane orientation to show that servant leadership is more global than western. Int J Leadersh Stud 2008;3:212-22.

18. Sendjaya S, Sarros JC, Santora JC. Defining and measuring servant leadership behaviour in organizations. J Manage Stud 2008;45:402-24.

19. Fry LW. Toward a theory of spiritual leadership. Leadership Quart 2003;14:693-727.

20. Bass BM. Two decades of research and development in transformational leadership. Eur J Work Organ Psychol 1999;8:9-32.
21. Rafferty AE, Griffin MA. Refining individualized consideration: distinguishing developmental leadership and supportive leadership. J Occup Organ Psychol 2006;79:37-61.

22. Barbuto JE, Wheeler DW. Becoming a servant leader: do you have what it takes? NebGuide G02-1481-A. Lincoln, NE: University of Nebraska, Nebraska Cooperative Extension, 2002.

23. Neill MW, Saunders NS. Servant leadership: enhancing quality of care and staff satisfaction. J Nurs Adm 2008;38:395-400.

24. Russell RF, Stone AG. A review of servant leadership attributes: developing a practical model. Leadersh Organ Dev J 2002;23:145-57.

25. Anderson H. Myths about "Not-Knowing”. Fam Proc 2005;44: 497-504.

26. Gergen KJ. Relational being: beyond self and community. New York: Oxford University Press, 2009.

27. Garza R. She teaches you like if she were your friend: Latino high school students describe attributes of a caring teacher. J Bord Educ Res 2007;6:81-92.

28. Shek DT, Yu L, Fu X. Confucian virtues and Chinese adolescent development: a conceptual review. Int J Adolesc Med Health 2013;25:335-44.

29. Han Y, Zhu Y, Peng Z, Le J, Wang S. Chinese servant leadership: a comparative study between public and business sector organisations. Service Systems and Service Management (ICSSSM): 9th International Conference on IEEE, 2012;643-46.

30. Ferris R. How organizational love can improve leadership. Organ Dyn 1988;16:41-51.

31. Ahmar NE. da Vinci's encephalogram: in search of significant brain signals. Dissertation. University of Maryland, 2005.

32. Maxwell JC. The 21 irrefutable laws of leadership. Nashville, TN: Thomas Nelson, 1998.

33. Covey SR. Principle-centered leadership. New York: Simon Schuster, 1991.

34. Kronemeyer R. Totally fit living: a 30-day program for total health and happiness. Deerfield Beach, FL: Health Communications, 1996.

35. Merriam G. Webster's new collegiate dictionary. Springfield, MA: GC Merriam, 1979.

36. Undung Y, de Guzman AB. Understanding the elements of empathy as a component of care-driven leadership. J Leadersh Stud 2009;3:19-28.

37. Spears LC, Lawrence M. Practicing servant-leadership. Leader to Leader 2004;34:7-11.

38. Kouzes M, Posner B. The leadership challenge. San Francisco, CA: Jossey-Bass, 2007.

39. Northouse PG. Leadership theory and practice, 4th ed. London: Sage, 2007.

40. Stone AG, Russell RF, Patterson K. Transformational versus servant leadership: a difference in leader focus. Leadersh Organ Dev J 2004;25:349-61.

41. McMinn TF. The conceptualization and perception of biblical servant leadership in the Southern Baptist convention. Dissertation. Southern Baptist Theological Seminary, 2001.

42. Waterman H. Principles of 'servant leadership' and how they can enhance practice. Nurs Manage 2011;17:24-6.

43. Blanchard K. Servant-leadership revisited. In: Spears LC, editor. Insights on leadership: service, stewardship, spirit and servantleadership. New York: John Wiley,1998:21-8.

44. Dubs HH. The attitude of Han Kao-Tsu to Confucianism. J Am Orient Soc 1937;57:172-80. 
45. Chen XP, Eberly MB, Chiang TJ, Farh JL, Cheng BS. Affective trust in Chinese leaders linking paternalistic leadership to employee performance. J Manage 2014;40:796-819.

46. Shek DT, Yu L, Ma CM, Sun RC, Liu TT. Development of a creditbearing service leadership subject for university students in Hong Kong. Int J Adolesc Med Health 2013;25:353-61.

47. Rhyne B. Urban middle school students' perceptions of math and science teachers' caring behaviors and student's self reports of academic competence. Dissertation. Rochester Institute of Technology, 2007.

48. Strutton D. Essay: a cancer patient's perspective on how and why care providers should pursue healing partnerships. Health Mark Q 2002;19:71-91.

49. Lapierre J. The quality-value relationship in the process of evaluating professional services: the case of consulting engineering. Dissertation. University of Quebec, 1993.

50. Patterson KA. Servant leadership: a theoretical model. Dissertation. Regent Univ, 2003.

51. Washington RR, Sutton CD, Feild HS. Individual differences in servant leadership: the roles of values and personality. Leadersh Organ Dev J 2006;27:700-16.

52. Senge P. Creating quality communities. In: Gozdz K, editor. Community Building: renewing spirit \& learning in business. San Francisco, CA: Sterling, 1995:49-55.

53. Swick KJ. Nurturing decency through caring and serving during the early childhood years. Early Child Educ J 2001;29:131-7.

54. Tyler TR, Blader SL. The group engagement model: procedural justice, social identity, and cooperative behavior. Pers Soc Psychol Rev 2003;7:349-61.
55. Chung P. HKI-SLAM's core beliefs (CB 1-7) about service leadership and management. Available at: http://server.gopublic. com.hk:3993/slam/index.php? $r=$ article\&catid=2\&aid $=24$. Accessed: 29 Nov 2013.

56. Freeman NK, Swick K. Serving and learning at a university laboratory school: students from birth through adulthood benefit when service learning is integrated into the preservice curriculum. J Early Child Teach Educ 2000;21:93-105.

57. Farling ML, Stone AG. Winston BE. Servant leadership: setting the stage for empirical research. J Leadersh Organ Stud 1999;6:49-72.

58. Chen CY, Chen CH, Li Cl. The influence of leader's spiritual values of servant leadership on employee motivational autonomy and eudaemonic well-being. J Relig Health 2013;52:418-38.

59. Pellegrini EK, Scandura TA. Paternalistic leadership: a review and agenda for future research. J Manage 2008;34:566-93.

60. Recipe for a Strong Relationship. Available at: http://www. recipeforastrongrelationship.com/relationship-quotes-live/. Accessed: 01 Dec 2013.

61. Madden PB. Diabetes and depression: challenges and some opportunities preface. Diabetes Spectr 2010;23:7-9.

62. Eisenberger R, Stinglhamber F, Vandenberghe C, Sucharski IL, Rhoades L. Perceived supervisor support: contributions to perceived organizational support and employee retention. J Appl Psychol 2002;87:565-73.

63. Kroth M, Keeler C. Caring as managerial strategy. Hum Resource Dev Rev 2009;8:506-31.

64. Spears L. Character and servant leadership: ten characteristics of effective, caring leaders. J Virtues Leadersh 2010;1:25-30. 